\author{
Katarzyna Leśniewska-Napierała \\ Uniwersytet Łódzki \\ Instytut Zagospodarowania Środowiska i Polityki Przestrzennej \\ katarzyna.lesniewska@geo.uni.lodz.pl
}

Tomasz Napierała

Uniwersytet Łódzki

Instytut Geografii Miast i Turyzmu

tomasz.napierala@geo.uni.lodz.pl

\title{
FUNKCJA HOTELARSKA W REWITALIZACJI OBSZARÓW WIEJSKICH STUDIUM PRZYPADKÓW W WOJEWÓDZTWIE POMORSKIM
}

\begin{abstract}
Abstrakt: Artykuł służy wskazaniu optymalnych lokalnych relacji społecznych, gospodarczych i geograficznych, sprzyjających efektywnej realizacji inwestycji hotelarskich $w$ ramach rewitalizacji obszarów wiejskich. Wskazany cel zostanie osiągnięty poprzez studia przypadków czterech hoteli działających w zrewitalizowanych obiektach zabytkowych na terenach wiejskich województwa pomorskiego. Wielokrotne studium przypadku zostanie wykonane w oparciu o złożenie następujących metod: 1) analizy danych zastanych dotyczących działalności badanych hoteli, 2) inwentaryzacji kartograficznej obszarów w skali mikro i mezo, na których zlokalizowane są badane hotele, 3) strukturyzowanych indywidualnych wywiadów pogłębionych z właścicielami lub zarządzającymi badanymi hotelami oraz wójtami lub odpowiedzialnymi za promocję pracownikami urzędów gmin, na terenie których działają badane hotele.
\end{abstract}

Słowa kluczowe: rewitalizacja, wieś, funkcja hotelarska, Pomorze.

\section{WPROWADZENIE}

Celem autorów niniejszego artykułu jest wskazanie relacji społecznych, gospodarczych i geograficznych, które na poziomie lokalnym tworzą odpowiedni klimat dla efektywnej realizacji inwestycji hotelarskich w ramach rewitalizacji obszarów wiejskich. Badania empiryczne, stanowiące podstawę opracowania niniejszego tekstu, zrealizowano jako wielokrotne studium przypadku skategoryzowanych hoteli działających w zrewitalizowanych założeniach rezydencyjnych na obszarach wiejskich województwa pomorskiego. Wśród 199 hoteli działających w województwie pomorskim, zidentyfikowano 45 zlokalizowanych na obszarach wiejskich, z czego cztery obiekty stanowia przykład wprowadzenia nowej funkcji w ramach rewitalizacji obiektów zabytkowych (założeń pałacowo-parkowych lub dworsko-parkowych). Wszystkie cztery hotele zostały poddane badaniu: hotel Spichrz w Borczu (pow. kartuski, gm. Somonino), hotel Wieniawa w Rekowie Górnym (pow. pucki, gm. Puck), hotel Pałac Ciekocinko w Ciekocinku (pow. wejherowski, gm. Choczewo) i hotel Pałac Godętowo w Godętowie (pow. wejherowski, gm. Łęczyce). Autorzy zdecydowali się na analizę wyłącznie hoteli skategoryzowanych ze względu na fakt, iż wymagania stawiane takim obiektom mają najbardziej sformalizowany charakter (Rozporządzenie Ministra Gospodarki i Pracy $z 19$ sierpnia 2004 r. w sprawie obiektów hotelarskich $i$ innych obiektów, w których sa świadczone ustugi hotelarskie, Dz.U. 2004, nr 188, poz. 1945 z późn. zm.). Wydaje się, że uruchomienie skategoryzowanego hotelu $\mathrm{w}$ ramach rewitalizacji zabytkowych założeń rezydencjonalnych wiąże się ze zdecydowanie największymi wyzwaniami w porównaniu z każdą inną działalnością hotelarską. Badania empiryczne (analizę danych zastanych, inwentaryzację kartograficzną i wywiady pogłębione) przeprowadzono w maju 2017 r.

Artykuł zorganizowany został w następujący sposób. Na podstawie literatury przedstawiono ideę rewitalizacji obszarów wiejskich poprzez wprowadzenie funkcji hotelarskiej, wskazano dotychczas zdiagnozowane wady i zalety introdukowania omawianej funkcji w ramach rewitalizacji, zaprezentowano wyzwania omawianego procesu. Następnie szczegółowo omówiono metodykę zastosowanego wielokrotnego 
studium przypadku. Prezentując wyniki odniesiono się do kilku istotnych zagadnień. Na podstawie analizy danych zastanych dokonano ogólnej charakterystyki hoteli działających w zrewitalizowanych założeniach pałacowo-parkowych na obszarach wiejskich województwa pomorskiego. Przeprowadzona w mikroskali inwentaryzacja kartograficzna pozwoliła wskazać funkcje na obszarze zrewitalizowanych założeń parkowo-pałacowych, w których współcześnie działają hotele. Wyniki inwentaryzacji w mezoskali umożliwiły ocenę potencjału województwa pomorskiego do wprowadzania funkcji hotelarskiej w ramach rewitalizacji obszarów wiejskich. Wreszcie, dzięki realizacji indywidualnych pogłębionych wywiadów scenariuszowych możliwe było określenie problemów, wyzwań i korzyści rewitalizacji wiejskich założeń pałacowo-parkowych $\mathrm{w}$ badanym regionie poprzez wprowadzenie funkcji hotelarskiej.

\section{IDEA REWITALIZACJI OBSZARÓW WIEJSKICH POPRZEZ WPROWADZENIE FUNKCJI HOTELARSKIEJ}

Wprowadzenie funkcji hotelarskiej jest jednym ze sposobów rewitalizacji obszarów wiejskich. Dzięki inwestycjom hotelarskim podejmowanym $\mathrm{w}$ ramach działań rewitalizacyjnych powinny powstawać nowe miejsca pracy, inwestycje powinny służyć podnoszeniu świadomości środowiskowej, kulturowej, społecznej i ekonomicznej lokalnej społeczności. Należy jednak zauważyć, że rozbieżne mogą być cele najważniejszych interesariuszy introdukowanej funkcji hotelarskiej. Mowa $\mathrm{z}$ jednej strony o inwestorach lub zarządzających hotelami, z drugiej - mieszkańcach rewitalizowanej przestrzeni wiejskiej i ich przedstawicielach.

Rozwój turystyki, a w szczególności rozwój bazy noclegowej, jest postrzegany jako katalizator wielofunkcyjnego rozwoju obszarów wiejskich, komplementarny w stosunku do produkcji rolnej. Introdukowanie funkcji turystycznej, w tym hotelarskiej, następuje bardzo często w ramach działań rewitalizacyjnych. Mowa o sytuacji, gdy nowe funkcje uzupełniaja lub zastępują dotychczasowe, a w konsekwencji eliminowane są istniejące niedostatki i konflikty przestrzenne, funkcjonalne, ekologiczne, społeczne i gospodarcze (KORELESKI 2007, WŁODARCZYK 2011). Wprowadzenie funkcji hotelarskiej $w$ ramach rewitalizacji obszarów wiejskich jest szczególnie pożądane na terenach o relatywnie niewielkiej rolniczej przestrzeni produkcyjnej, charakteryzującej się dodatkowo niską jakością, a w konsekwencji niską efektywnością gospodarowania. Z drugiej strony, introdukowanie funkcji hotelarskiej powinno odbywać się na obszarach o wysokim potencjale turystycznym, zarówno o genezie przyrodniczej, jak i antropogenicznej (BIEŃKOWSKI 2001). Z pewnością znamiona te wyczerpują tereny wiejskie województwa pomorskiego.

Należy mieć świadomość, że wprowadzenie funkcji hotelarskiej na obszary wiejskie może prowadzić do negatywnych konsekwencji, m.in. akulturacji, a więc przyjęcia przez mieszkańców wsi wzorców kulturowych sprowadzonych przez zarządzających, pracowników i gości hoteli (BIEŃKOWSKI 2001). Wprowadzenie funkcji hotelarskiej może prowadzić do intensyfikacji i umasowienia ruchu turystycznego, a w konsekwencji do kulturowej, społecznej, ekonomicznej i fizjonomicznej homogenizacji przestrzeni wiejskiej: upodobnienia się wiejskiej przestrzeni recepcyjnej do innych obszarów turystycznych, jak również upodobnienia się do obszarów generujących ruch turystyczny (DURYDIWKA 2014, MIKA 2007). Dlatego rozwijanie omawianej funkcji na wsi powinno odbywać się z należytą ostrożnością, z uwzględnieniem kontekstu społecznego, kulturowego, ekonomicznego, ekologicznego i krajobrazowego rewitalizowanego miejsca (BIEŃKOWSKI 2001, MYGA-PIĄTEK 2012). Z tego względu charakter funkcji hotelarskiej wprowadzanej do rewitalizowanych założeń pałacowo-parkowych powinien być znacząco odmienny od specyfiki nowoczesnego miejskiego obiektu. Efektywna oferta hotelu działającego w zrewitalizowanym pałacu powinna być ofertą luksusową, opartą na doświadczeniu piękna i harmonii wiejskiego krajobrazu, jak również na doświadczeniu lokalnego dziedzictwa kulturowego i historycznego (ROUBA, CUDNY 2011, CUDNY, ROUBA 2012). W efekcie rewitalizacja obszarów wiejskich poprzez introdukowanie funkcji hotelarskiej powinna inicjować rozwój kulturowej samoświadomości mieszkańców wsi (DURYDIWKA 2014), a jednocześnie sprzyjać zrównoważonemu rozwojowi (GONDA-SOROCZYŃSKA 2008, KRONENBERG 2011).

Jak podaje J. KIZIELEWICZ (2002), wprowadzenie funkcji hotelarskiej do rewitalizowanych obiektów noclegowych wiąże się z licznymi wyzwaniami, którym musi sprostać inwestor. Jednym z nich jest potencjalny konflikt pomiędzy postulatami ochrony obiektu zabytkowego (określona prawnie konieczność zachowania zabytkowej substancji) oraz wymaganiami stawianymi obiektom hotelarskim przez prawo i oczekiwania przyszłych gości (odpowiednie wyposażenie części wspólnych i pokoi). Widać więc, że już na poziomie prawnym może pojawić się konflikt pomiędzy ochroną tego, co zabytkowe (Ustawa z 23 lipca 2003 r. o ochronie zabytków i opiece nad zabytkami, Dz.U. 2003, nr 162, poz. 1568 z późn. zm.), a jednocześnie zapewnieniem funkcjonalności tego co użytkowe (Rozporządzenie Ministra Gospodarki i Pracy z 19 sierpnia 2004 r. w sprawie obiektów hotelarskich i innych obiektów, w których sq świadczone ustugi hotelarskie Dz.U. 2004, nr 188, 
poz. 1945 z późn. zm., LiTWIN, BACIOR, PIECH 2010). W. CUDNY i R. ROUBA (2012) piszą o swoistym determinizmie architektoniczno-funkcjonalnym, $\mathrm{w}$ efekcie którego zachowaniu elementów zabytkowych podporządkowane jest wprowadzenie nowej funkcji. Rodzi to określone konsekwencje produktowe (usługa noclegowa jest odpowiedzią nie tylko na potrzeby klienta, ale również postulaty opieki nad zabytkami), organizacyjne (istotnym interesariuszem wszystkich działań jest wojewódzki konserwator zabytków) i kosztowe (koszty inwestycyjne $\mathrm{w}$ przypadku wprowadzania funkcji hotelarskiej do obiektu zabytkowego są zazwyczaj znacząco wyższe niż $\mathrm{w}$ przypadku budowy nowego hotelu). Warto jednak pamiętać, że wprowadzenie funkcji hotelarskiej może być jedynym środkiem ochrony wiejskiego dziedzictwa kulturowego (GONDA-SOROCZYŃSKA 2008).

J. KRONENBERG (2011) odnotowuje różnorodne napięcia powstające pomiędzy inwestorem a lokalną społecznością na skutek introdukowania funkcji hotelarskiej w ramach podjętych działań rewitalizacyjnych zabytkowych założeń pałacowo-parkowych. Wskazuje na możliwy brak rekrutacji pracowników spośród lokalnej społeczności, ograniczone uczestnictwo lokalnej społeczności $\mathrm{w}$ wydarzeniach organizowanych $\mathrm{w}$ zrewitalizowanych obiektach, brak strategii komunikacji hotelarza $\mathrm{z}$ mieszkańcami. $\mathrm{Z}$ wyjątkiem ostatniego, przyczyny wymienionych problemów mogą leżeć zarówno po stronie lokalnej społeczności, jak $\mathrm{i}$ inwestora. Rozwiązań należy upatrywać $\mathrm{w}$ powiązaniu przedsiębiorstwa z miejscem, w którym ono działa i jego mieszkańcami: nawiązanie do lokalnych tradycji, zastosowanie marketingu skojarzonego hotelu i gminy, wsparcie lokalnej gospodarki poprzez większą otwartość na zatrudnianie mieszkańców oraz współpracę $\mathrm{z}$ lokalnymi dostawcami, stworzenie atrakcyjnej, również niekomercyjnej oferty dla mieszkańców (KRONENBERG 2011).

Niezależnie od omówionego wyżej ryzyka, funkcja hotelarska uznawana jest za jedną z najwłaściwszych funkcji wprowadzanych $w$ ramach rewitalizacji zabytkowych, wiejskich zespołów rezydencjonalnych. Warto podkreślić, że $\mathrm{w}$ przeciwieństwie do przywrócenia funkcji mieszkaniowej czy wprowadzenia funkcji muzealnej, funkcja hotelarska pozwala na osiągnięcie znacznie korzystniejszego efektu ekonomicznego (CUDNY, ROUBA 2012). Finalnie możliwe jest jednoczesne uwzględnienie postulatów ochrony zabytków, zabezpieczenie korzyści ekonomicznej dla inwestora, jak również - dzięki jednoczesnemu powiększeniu zasobów bazy noclegowej i przywróceniu atrakcyjności zrewitalizowanym walorom - zwiększenie liczby obsługiwanych turystów, a w konsekwencji osiągnięcie efektu mnożnikowego $\mathrm{w}$ gospodarce lokalnej (KONIECZNA-DOMAŃSKA 2015).

\section{METODYKA STUDIUM PRZYPADKU WYBRANYCH HOTELI W WOJEWÓDZTWIE POMORSKIM}

Celem niniejszego artykułu jest zdefiniowanie takich lokalnych relacji społecznych, gospodarczych i geograficznych, które sprzyjają realizacji inwestycji hotelarskich $\mathrm{w}$ ramach rewitalizacji obszarów wiejskich. Oznacza to ustalenie zasadności rewitalizacji i poszukiwanie korzyści z tego procesu zarówno dla przedsiębiorców zarządzających hotelami, jak i przedstawicieli samorządu gminnego, odpowiedzialnych za ochronę lokalnego dziedzictwa kulturowego i reprezentujących interesy mieszkańców. Tak zdefiniowany cel może zostać zrealizowany dzięki studiom przypadków czterech skategoryzowanych hoteli działających $\mathrm{w}$ zrewitalizowanych zabytkowych założeniach pałacowo-parkowych na terenach wiejskich województwa pomorskiego.

Niniejsze badanie jest deskryptywnym, wielokrotnym studium przypadku (YIN 2015). Zjawisko funkcjonowania obiektów noclegowych $\mathrm{w}$ rewitalizowanych obiektach zabytkowych (w tym zabytkowych założeniach pałacowo-parkowych) na obszarach wiejskich było przedmiotem wcześniejszych badań naukowych. Mimo podejmowania różnorodnych zagadnień, nie przygotowano dotąd na bazie studiów empirycznych opisu optymalnych relacji społecznych, gospodarczych i geograficznych sprzyjających wprowadzeniu funkcji hotelarskiej $w$ ramach działań rewitalizacyjnych, zarówno $\mathrm{z}$ perspektywy przedsiębiorcy prowadzącego hotel, jak i władz gminy dbających o dostępne zasoby dziedzictwa kulturowego oraz realizację celów mieszkańców i innych interesariuszy. Ze względu na powyższe zdecydowano się na deskryptywny charakter podjętych studiów. Autorzy przystępując do badania powzięli (uzasadnione, jak się okazało) obawy dotyczące możliwości pełnego rozpoznania każdego zidentyfikowanego przypadku rewitalizacji na obszarach wiejskich województwa pomorskiego. W związku z powyższym zdecydowali się na wielokrotne studium przypadku, a więc zbadanie wszystkich czterech zidentyfikowanych jednostek analizy. Udało się dzięki temu uniknąć sytuacji, w której brak możliwości zrealizowania metodycznie kompletnego studium przypadku pojedynczej jednostki podważyłby jakość całego badania. Wielokrotny charakter studium przypadku był zatem gwarancją przeprowadzenia generalizacji analitycznej. Pozwolił na opracowanie uogólnień odnoszących się do innych, podobnych przypadków.

Studium przypadku zostało wykonane w oparciu o triangulację następujących metod: 1) analizy danych zastanych odnoszących się do działalności badanych hoteli, 2) inwentaryzacji kartograficznej skategoryzo- 
wanych hoteli działających w zabytkowych założeniach pałacowo-parkowych na obszarach wiejskich województwa pomorskiego (mezoskala), jak również inwentaryzacji kartograficznej budynków zlokalizowanych na użytkowanych przez hotele terenach zrewitalizowanych założeń pałacowo-parkowych (mikroskala), 3) scenariuszowych indywidualnych wywiadów pogłębionych z właścicielami lub zarządzającymi badanymi hotelami oraz wójtami lub pracownikami urzędów gmin, na terenie których działają badane hotele.

Analiza danych zastanych powinna poprzedzać każdy projekt badawczy. Umożliwia gromadzenie i analizę już istniejących danych na temat badanego zjawiska. Pozwala zatem ustalić aktualny stan informacji dotyczących konkretnego badanego tematu. $\mathrm{Z}$ perspektywy prowadzenia badań jest działaniem koszto- i czasooszczędnym (MAKOWSKA, BOGUSZEWSKI 2013). W ramach analizy danych zastanych poszukiwano informacji jakościowych i ilościowych odnoszących się do badanych zjawisk w dokumentach strategicznych wytworzonych przez jednostki samorządu gminnego, na terenie których działają badane hotele. Mowa przede wszystkim o strategiach gminnych, studiach uwarunkowań i kierunków przestrzennego zagospodarowania, jak również gminnych programach opieki nad zabytkami. Przeprowadzono również wtórną analizę statystyczną i kartograficzną korzystając z następujących źródeł danych: wojewódzkiej i gminnych ewidencji zabytków oraz centralnego wykazu obiektów hotelarskich prowadzonego przez Ministerstwo Sportu i Turystyki.

Kolejną wykorzystaną metodą badawczą w ramach opisywanego wielokrotnego studium przypadku była inwentaryzacja kartograficzna, inaczej nazywana również kartograficzną metodą badań. Definicje inwentaryzacji kartograficznej akcentują przede wszystkim następujące procesy składające się na omawianą metodę badawczą: 1) rozpoznanie rzeczywistości z wykorzystaniem aparatu kartograficznego, 2) porządkowanie i archiwizowanie informacji uzyskanej na etapie pierwszym, 3) przetworzenie informacji uporządkowanej na etapie drugim, i wreszcie 4) wnioskowanie na podstawie uporządkowanej i przetworzonej informacji uzyskanej na etapie trzecim (RATAJSKI 1973, SALISZCZEW 1998). W opisywanym badaniu inwentaryzację kartograficzną wykonano w dwóch skalach przestrzennych: 1) mezo, a więc w skali całego województwa pomorskiego, w którym zinwentaryzowano hotele działające $\mathrm{w}$ zrewitalizowanych zabytkowych założeniach pałacowo-parkowych na terenach wiejskich, i 2) mikro, a więc w skali pojedynczych lokalizacji (działek) wcześniej zidentyfikowanych hoteli, na których zinwentaryzowano pojedyncze budynki pod kątem pełnionych przez nie funkcji. Mapy, które były podstawą prac terenowych i kameralnych w inwentaryzacji kartograficznej zarówno na poziomie mikroskalowym, jak i mezoskalowym wykonano korzystając z zasobów Bazy Danych Obiektów Topograficznych, udostępnianej przez Centralny Ośrodek Dokumentacji Geodezyjnej i Kartograficznej.

Ostatnią z wykorzystanych w opisywanym badaniu metod były strukturyzowane indywidualne wywiady pogłębione. Należy zauważyć, że w ramach wywiadów jakościowych wiedza gromadzona jest dzięki niesymetrycznej interakcji pomiędzy prowadzącym wywiad a respondentem. Wspomniana asymetria wynika z faktu, że wyłącznie jedna strona (prowadzący wywiad) decyduje o strukturze i celu interakcji. Wywiad zatem nie jest rozmowa, tylko ustrukturyzowanym, a więc opartym o scenariusz zadawaniem pytań przez prowadzącego wywiad i wysłuchiwaniem odpowiedzi respondenta (KVALE 2011). W niniejszym badaniu przeprowadzono wywiad badawczy według dwóch oddzielnych scenariuszy, jednego dla przedstawicieli jednostek samorządu gmin-

Tab. 1. Scenariusz wywiadu pogłębionego z przedstawicielami jednostek samorządu gminnego na terenach wiejskich województwa pomorskiego, na których działają skategoryzowane hotele zlokalizowane w zrewitalizowanych, zabytkowych założeniach pałacowo-parkowych

\begin{tabular}{|l|l|}
\hline \multicolumn{1}{|c|}{ Pytania badawcze } & \multicolumn{1}{c|}{ Pytania szczegółowe } \\
\hline $\begin{array}{l}\text { Jaka jest celowość wprowadzania } \\
\text { funkcji hotelowej w ramach } \\
\text { rewitalizacji zabytkowych obiektów? }\end{array}$ & $-\begin{array}{l}\text { Jakie funkcje powinny być wprowadzane w ramach rewitalizacji obiektów } \\
\text { zabytkowych? } \\
\text { Czy i dlaczego celowe jest wprowadzenie funkcji hotelowej w ramach rewitalizacji } \\
\text { obiektów zabytkowych? }\end{array}$ \\
\hline $\begin{array}{l}\text { Jakie, z perspektywy gminy, są } \\
\text { korzyści z rewitalizacji i wpro- } \\
\text { wadzenia funkcji hotelowej do } \\
\text { rewitalizowanego obiektu? }\end{array}$ & $\begin{array}{l}\text { Jakie są korzyści z rewitalizacji i wprowadzenia funkcji hotelowej do rewitalizowa- } \\
\text { nego obiektu z perspektywy lokalnej społeczności? }\end{array}$ \\
$-\begin{array}{l}\text { Jakie są korzyści z rewitalizacji i wprowadzenia funkcji hotelowej do rewitalizo- } \\
\text { wanego obiektu z perspektywy miejscowych przedsiębiorstw? }\end{array}$ \\
$-\begin{array}{l}\text { Jakie oddziaływanie na lokalne dziedzictwo i kulturę miała rewitalizacja i wprowa- } \\
\text { dzenie funkcji hotelowej do rewitalizowanego obiektu? }\end{array}$
\end{tabular}

Źródło: opracowanie własne. 
Tab. 2. Scenariusz wywiadu pogłębionego z przedstawicielami skategoryzowanych hoteli działających w zrewitalizowanych zabytkowych założeniach pałacowo-parkowych na terenach wiejskich województwa pomorskiego

\begin{tabular}{|l|c|}
\hline \multicolumn{1}{|c|}{ Pytania badawcze } & \multicolumn{1}{c|}{ Pytania szczegółowe } \\
\hline $\begin{array}{l}\text { Jakie jest uzasadnienie rewitalizacji } \\
\text { i wprowadzenia funkcji hotelowej } \\
\text { do rewitalizowanego obiektu? }\end{array}$ & $\begin{array}{r}\text { - Dlaczego zdecydowano się na rewitalizację istniejącego obiektu zabytkowego zamiast } \\
\text { budowy nowego hotelu? }\end{array}$ \\
- & $\begin{array}{l}\text { Dlaczego zdecydowano się na działalność hotelową w ramach rewitalizacji? } \\
-\end{array}$ \\
\hline $\begin{array}{l}\text { Jakie, z perspektywy hotelu, są był jedynym rodzajem działalności rozpatrywanym w ramach rewitalizacji? } \\
\text { korzyści z rewitalizacji i wprowa- } \\
\text { dzenia funkcji hotelowej do rewita- } \\
\text { lizowanego obiektu? }\end{array}$ & $\begin{array}{l}\text { - Jakie są korzyści z rewitalizacji i wprowadzenia funkcji hotelowej do rewitalizowa- } \\
\text { nego obiektu z perspektywy lokalnej społeczności? }\end{array}$ \\
& $\begin{array}{l}\text { Jakie są korzyści z rewitalizacji i wprowadzenia funkcji hotelowej do rewitalizowa- } \\
\text { nego obiektu z perspektywy miejscowych przedsiębiorstw? }\end{array}$ \\
& $\begin{array}{l}\text { Jakie oddziaływanie na lokalne dziedzictwo i kulturę miała rewitalizacja i wprowa- } \\
\text { dzenie funkcji hotelowej do rewitalizowanego obiektu? }\end{array}$ \\
\hline
\end{tabular}

Źródło: opracowanie własne.

nego na terenach wiejskich województwa pomorskiego, na których działają skategoryzowane hotele zlokalizowane $\mathrm{w}$ zrewitalizowanych, zabytkowych założeniach pałacowo-parkowych, a drugiego dla hotelarzy. Scenariusze zaprezentowano w tabelach (tab. 1 i 2). Pierwotnie zakładano przeprowadzenie dwóch wywiadów dla każdej z czterech jednostek wielokrotnego studium przypadku: jednego z przedstawicielem hotelu i jednego $\mathrm{z}$ przedstawicielem samorządu gminnego. Ze względu na odmowę uczestnictwa $w$ badaniu zrealizowano trzy wywiady $\mathrm{z}$ przedstawicielami gmin i tylko jeden $z$ hotelarzem. Ze względu na obawy dotyczące szczerości ujawnianych sądów, jak i niewielkie zainteresowanie uczestnictwem $\mathrm{w}$ badaniu po stronie przedsiębiorców, zrezygnowano $\mathrm{z}$ rejestracji prowadzonych wywiadów. Bazowano na szczegółowych, substytucyjnych notatkach sporządzanych jednocześnie przez dwójkę badaczy. Ze względu na powyższe ograniczenia uzyskane wyniki, szczególnie w odniesieniu do zebranych opinii przedsiębiorców, należy traktować z dużą ostrożnością.

\section{OGÓLNA CHARAKTERYSTYKA HOTELI DZIAŁAJACYCH \\ W ZREWITALIZOWANYCH ZAŁOŻENIACH PAEACOWO-PARKOWYCH NA OBSZARACH WIEJSKICH WOJEWÓDZTWA POMORSKIEGO}

Tereny dzisiejszego województwa pomorskiego pokrywają się ze średniowiecznymi granicami Pomorza Wschodniego pozostającego $\mathrm{w}$ strefie zmieniających się wpływów polskich i niemieckich, jak również skandynawskich. Siedziby szlacheckie zaczęły na tym terenie powstawać już w XVII w. Najwięcej wiejskich budowli rezydencjonalnych szlachty i zamożnego ziemiaństwa (założeń folwarcznych, dworsko-parkowych, pałacowo-parkowych) pochodzi z II poł. XIX w. i początku XX (GAWEE 2013). Bogate dziedzictwo może być szansą rozwoju danego obszaru, choć wymaga to stworzenia odpowiednich warunków (LEŚNIEWSKA-NAPIERAEA 2017). Jak zauważa M. KOZAK (2008), historyczna rola dworów i pałaców jako siedzib najzamożniejszych właścicieli ziemskich uległa zanikowi. Efektem tego procesu w połączeniu z utrata znaczenia rolnictwa na obszarach wiejskich jest możliwość wprowadzenia nowej funkcji do tych obiektów, np. hotelarskiej, restauracyjnej czy muzealnej. Poniżej przedstawiono charakterystykę badanych, zrewitalizowanych założeń dworsko-parkowych i pałacowo-parkowych oraz działających w nich skategoryzowanych hoteli. Jeżeli nie podano inaczej, podstawowym źródłem informacji były materiały udostępnione przez hotele.

Hotel Spichrz (fot. 1) położony jest we wsi Borcz opodal Hopowa w gminie Somoniono w powiecie kartuskim. Jest to wieś folwarczna o typowym układzie ulicówki. Zabytkową strukturę wsi oprócz zespołu dworsko-folwarcznego wraz z dworem, gorzelnią i parkiem, tworzy wielorodzinna zabudowa folwarczna wzdłuż drogi (Gminny program opieki nad zabytkami gminy Somonino na lata 2017-2020 2017, Program opieki nad zabytkami powiatu kartuskiego na lata 2015-2018 2015). Pierwsze wzmianki o wsi pochodzą już z 1241 r. Początkowo wieś funkcjonowała jako dobro rycerskie, z czasem jednak stała się majątkiem ziemskim. Na początku XIX w. na skutek wojen napoleońskich znaczna część wsi uległa zniszczeniu. Po pożarze dworu $\mathrm{w}$ początkach XX w. na jego miejscu wzniesiono murowany budynek. Budowę ukończono w 1911 r., zaś park dworski został założony na przełomie XIX 
i XX w. (Strategia rozwoju gminy Somonino na lata 20122019). W roku 1920 majątek przejął Albert Hoene, który rozpoczął hodowlę bydła, owiec i trzody chlewnej. Podczas II wojny światowej majątek nie uległ zniszczeniu, jednakże ówcześni właściciele zdecydowali się na opuszczenie obiektu. W roku 1945 założenie pałacowo-parkowe stało się częścią PGR.

W roku 1999 majątek trafił w ręce prywatne i rozpoczęto proces rewitalizacji obiektu. Rewitalizacją objęto dwór oraz spichlerz, który zaadaptowano na hotel i restaurację. Zabytkowy dwukondygnacyjny dwór został zbudowany na planie prostokąta i zlokalizowany w taki sposób, by zamknać dziedziniec gospodarczy. Po stronie północnej dworu znajduje się trzykondygnacyjny budynek magazynowy $\mathrm{z}$ nieotynkowanej cegły, wykorzystywany obecnie jako hotel i restauracja. Największym wyzwaniem dla nowego właściciela było przystosowanie spichlerza do pełnienia nowej funkcji. Obecnie obiekt dysponuje 14 pokojami gościnnymi i specjalizuje się w organizacji spotkań biznesowych, konferencji i bankietów. Od zachodu do zespołu dworskiego przylega park, na którego terenie organizowane są imprezy okolicznościowe. Co ciekawe, obok zabudowy hotelowej, znajduje się największa polska fabryka przerobu pierza Polskie Północne Pierze i Puch Sp. z o.o. Na terenie założenia znajdują się dwa punkty sprzedaży, tj. sklep firmowy oraz recepcja hotelowa. Dodatkowo obsługa hotelowa oferuje wycieczki po fabryce.

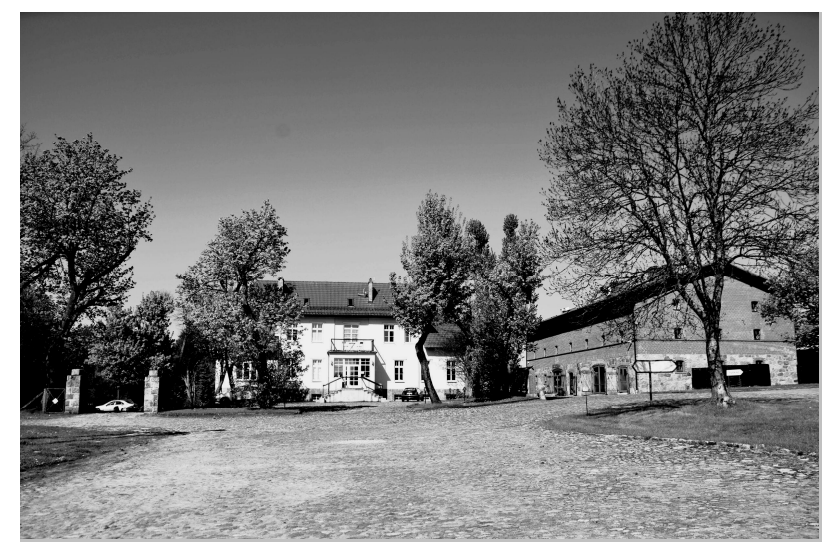

Fot. 1. Hotel Spichrz w Borczu

(fot. K. Leśniewska-Napierała, 2017)

Hotel Wieniawa (fot. 2) położony jest we wsi Rekowo Górne w gminie Puck. Pierwsza wzmianka na temat wsi pochodzi już z 1392 r. Wieś była wówczas własnością rycerską. Eklektyczny pałac powstał w samym centrum Rekowa Górnego w 1871 r. z inicjatywy radcy Hagena z Sobowidza. Obiekt został zaprojektowany w stylu włoskim na planie prostokąta z czworoboczną wieżą widokową (Program opieki nad zabytkami powiatu puckiego na lata 2016-2019). Do czasów II wojny światowej obiektem zarządzał Paul Mahncke, z którego inicjatywy wybudowano m.in. gorzelnię i kuźnię. Po wojnie $\mathrm{w}$ obiekcie mieściła się siedziba PGR, a od 1968 r. funkcjonował Instytut Warzywnictwa.

W 1994 r. pałac został kupiony przez prywatnego właściciela i rozpoczęto rewitalizację obiektu pod ścisłym nadzorem konserwatora zabytków. Zadbano także o odrestaurowanie parku okalającego budynek pałacu. W ramach rewitalizacji wprowadzono funkcję hotelarską. Czterogwiazdkowy obiekt posiada obecnie 31 pokoi gościnnych. Dodatkowo hotel dysponuje kortami tenisowymi, boiskiem do siatkówki, koszykówki, piłki nożnej i unihokeja oraz polem do minigolfa. W ofercie hotelu znajdują się także usługi SPA oraz wczasy dla osób z cukrzycą lub nietolerancją glutenu.

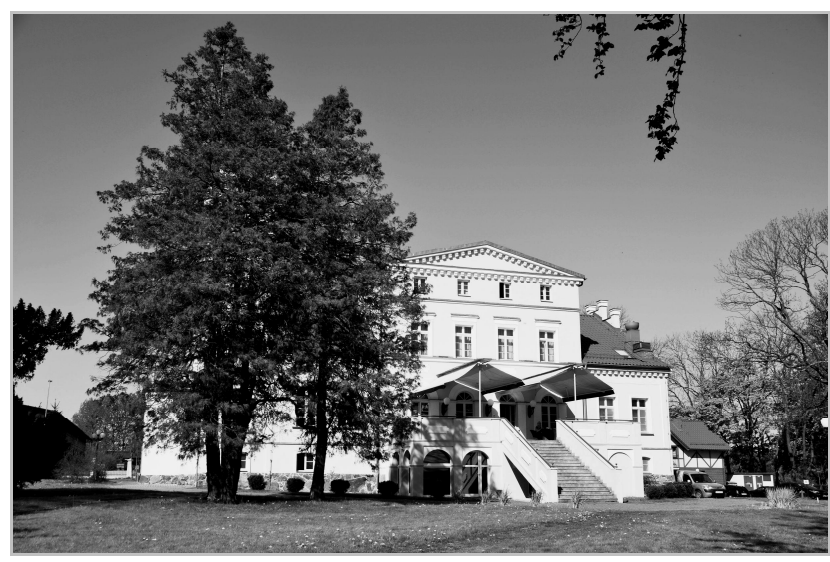

Fot. 2. Hotel Wieniawa w Rekowie Górnym (fot. K. Leśniewska-Napierała, 2017)

Hotel Pałac Ciekocinko (fot. 3) zlokalizowany jest w gminie Choczewo w powiecie wejherowskim. Na temat wsi Ciekocinko można przeczytać w archiwalnych dokumentach z 1362 r. Zabytkowy dwór został wybudowany w 1910 r., zaś park i folwark pochodzą z końca XIX w. W roku 1945 obiekt przeszedł na własność Państwowych Nieruchomości Ziemskich, zaś w 1950 r. utworzono w nim PGR. W roku 2004 obiekt przejął prywatny właściciel i rozpoczęto proces rewitalizacji obiektu (Gminny program opieki nad zabytkami w gminie Choczewo na lata 2017-2020). Ze względu na wieloletnie zaniedbania budynek był w bardzo złym stanie technicznym, a wiele elementów konstrukcyjnych i wyposażenia zostało skradzionych. Restauracja obiektu odbywała się w oparciu o oryginalne założenia projektu z zachowaniem detali architektonicznych. Nowy właściciel zadbał o rekonstrukcję m.in. drzwi wejściowych. Dodatkowo dokonano rozbiórki budynków wybudowanych podczas funkcjonowania PGR (Pałac Ciekocinko 2017). Pałac otoczony jest parkiem od zachodu, zaś od południa i wschodu graniczy $\mathrm{z}$ terenami rolnymi. Pałac Ciekocinko Hotel Resort \& Wellness jest skategoryzowany jako 
obiekt pięciogwiazdkowy. Pokoje zostały urządzone w stylu secesyjnym, biedermeier oraz art déco. Obiekt dysponuje 28 pokojami gościnnymi i posiada zaplecze konferencyjne. Dodatkowo w zabytkowej powozowni znajduje się 10 pokoi urządzonych w stylu cottage. Hotel oferuje m.in. zabiegi SPA, lekcje jazdy konnej czy degustację win. W ramach kompleksu pałacowo-parkowego funkcjonuje również stadnina koni, a na jej terenie organizowane są zawody konne Baltica.

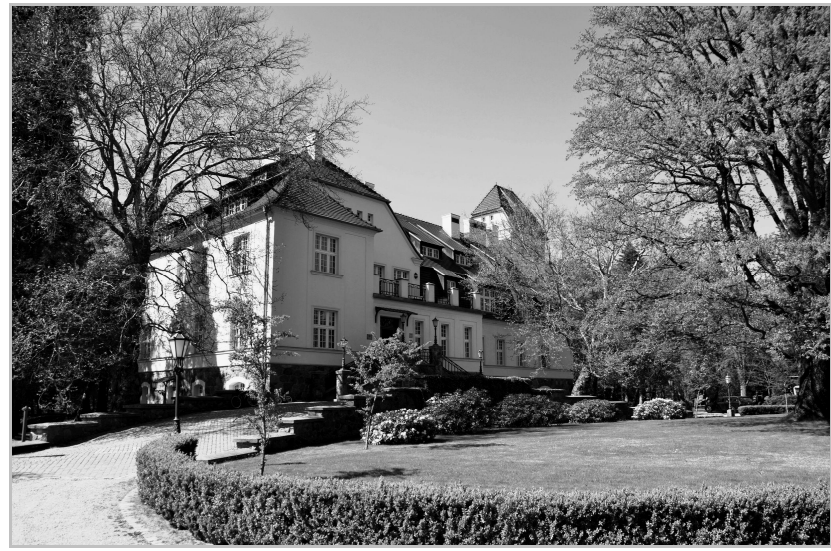

Fot. 3. Hotel Pałac Ciekocinko w Ciekocinku (fot. K. Leśniewska-Napierała, 2017)

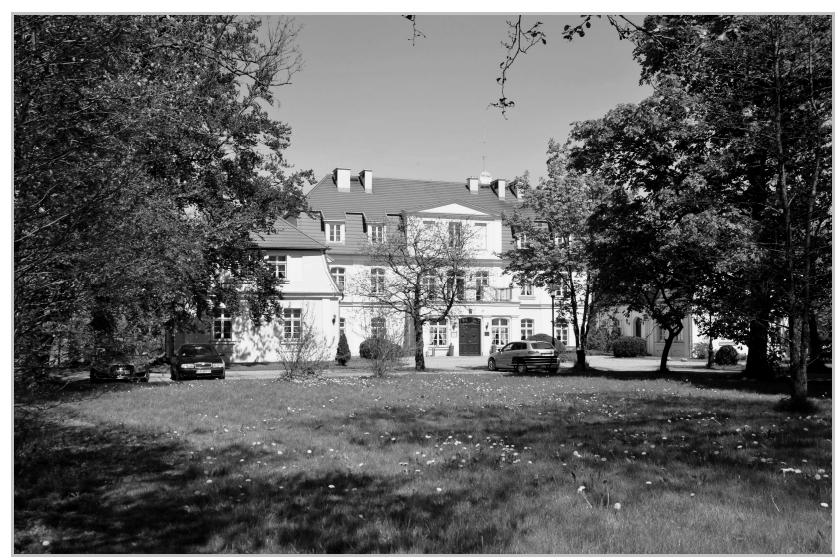

Fot. 4. Hotel Godętowo w Godętowie (fot. K. Leśniewska-Napierała, 2017)

Hotel Pałac Godętowo położony jest w gminie Łęczyce w powiecie wejherowskim. Pierwsza wzmianka majątku Godętowo pochodzi już z 1284 r. Majątek wielokrotnie zmieniał właścicieli, traktowany był jako lokata kapitału dla pomorskiej szlachty. W połowie XVII w. istniał już budynek dworu. W roku 1794 hrabia von Lehndorf utworzył na terenie majątku pierwszy teatr na Pomorzu. W roku 1820 dokonano rozbudowy pałacu, dobudowując skrzydła oraz ganek z tarasem prowadzącym do ogrodu. Podczas II wojny światowej wojska Wehrmachtu zajęły pałac, w którym utworzono siedzibę sztabu wywiadu wojskowego
(Strategia rozwoju gminy Łęczyce na lata 2010-2025). Po wojnie majątek przeszedł na własność Skarbu Państwa. Dwór, w którym urządzono mieszkania i biura z czasem popadł w ruinę. W 2006 r. pałac przeszedł $\mathrm{w}$ ręce prywatnych właścicieli i rozpoczęto trzyletnią rewitalizację, w ramach której uruchomiono działalność hotelową. Trzygwiazdkowy obiekt dysponuje aktualnie 20 pokojami gościnnymi. W hotelu organizowane są szkolenia i konferencje oraz imprezy okolicznościowe.

\section{REWITALIZACJA OBSZARÓW WIEJSKICH POPRZEZ WPROWADZENIE FUNKCJI HOTELARSKIEJ W WOJEWÓDZTWIE POMORSKIM}

Badania przeprowadzone na terenie wybranych zrewitalizowanych założeń pałacowo-parkowych w województwie pomorskim wykazały, że długotrwały proces przekształceń doprowadził do wykształcenia się w obrębie działek nowych funkcji (rys. 1). Jest to zgodne z wynikami ogólnopolskich badań R. ROUBY (2010), który wykazał, że omawiane przekształcenia działek oznaczały przede wszystkim uporządkowanie otoczenia, restaurację części parkowej, jak również rozbiórkę zbędnych, pozostających $\mathrm{w}$ złym stanie technicznym budynków, wprowadzenie nowej infrastruktury komunikacyjnej (ciągi komunikacyjne, parkingi), a także budowę nowych lub rozbudowę istniejących budynków w związku z rozwojem nowych funkcji. Proces introdukcji działalności hotelarskiej w zabytkowych dworach doprowadził w otaczających je parkach do rozwoju zróżnicowanej infrastruktury społecznej (WITKOWSKI, STAROŚCIC 2008), w tym do wykształcenia funkcji wypoczynkowej. Ze względu na pełnione funkcje spośród badanych założeń najbardziej wyróżnia się Spichrz w Borczu, na terenie którego obok hotelu i parku znajduje się fabryka puchowych kołder i poduszek. Pod względem stanu technicznego i spójnego zagospodarowania założenia na uwagę zasługuje pałac Ciekocinko, gdzie szczególnie imponująca jest część rezydencjonalna założenia.

Obok funkcji wykształconych $\mathrm{w}$ obrębie działek warto również wspomnieć o funkcjach pełnionych przez zrealizowane założenia względem całych wsi czy wręcz gmin. Badane obiekty mają z pewnością pozytywny wpływ na wizerunek gmin, w których są zlokalizowane. Można zatem mówić o funkcji marketingowej. Dodatkowo przez zachowanie swej tradycyjnej formy wykorzystywane są $\mathrm{w}$ upowszechnianiu wiedzy na temat dawnej architektury. Pełnią więc także funkcję dydaktyczną. Niewątpliwie wszystkie badane obiekty ze względu na swoją historię i archi- 

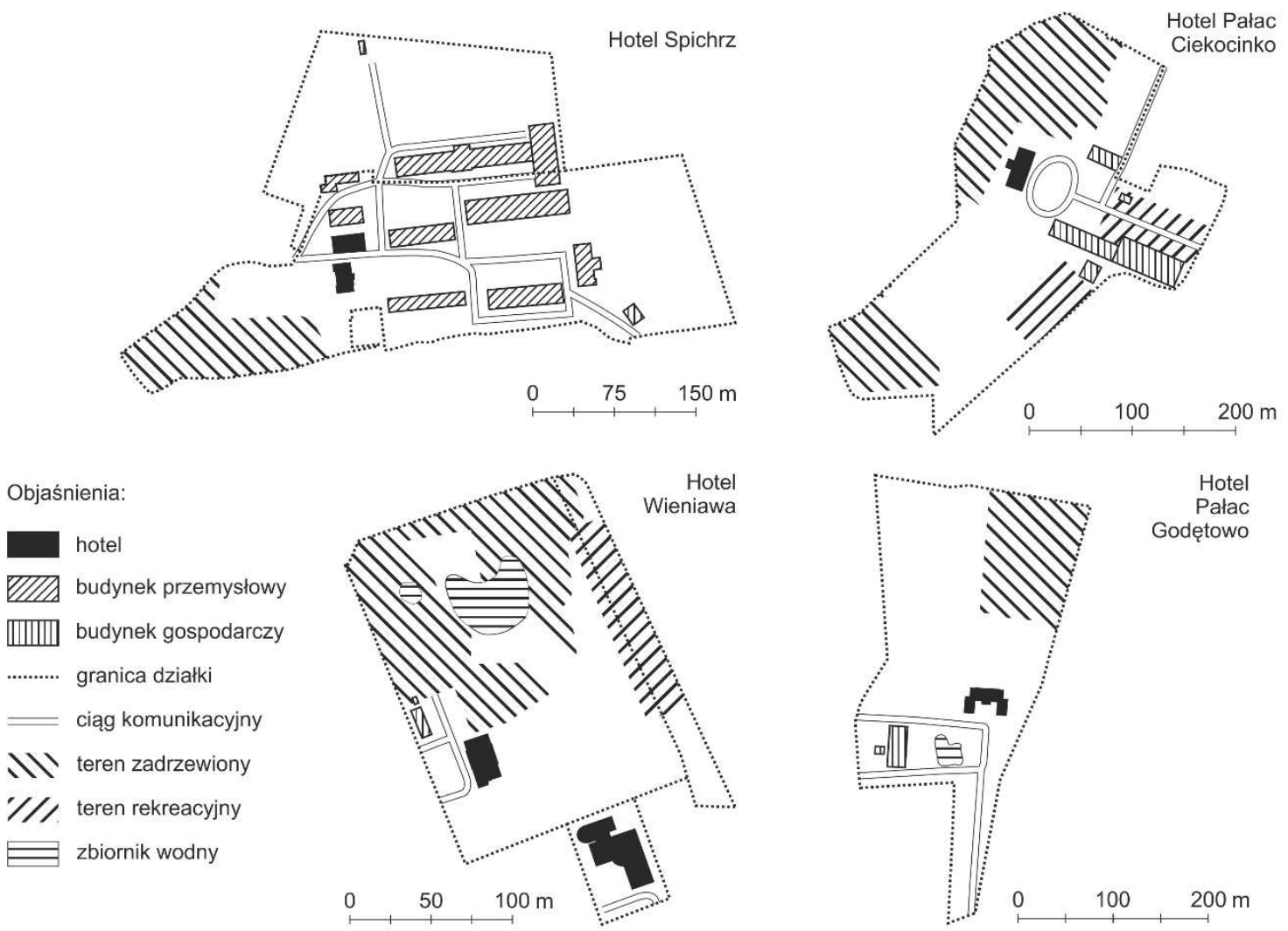

Rys. 1. Lokalizacja hoteli w zrewitalizowanych założeniach pałacowo-parkowych na obszarach wiejskich województwa pomorskiego

Źródło: opracowanie własne na podstawie autorskiej inwentaryzacji kartograficznej i Bazy Danych Obiektów Topograficznych

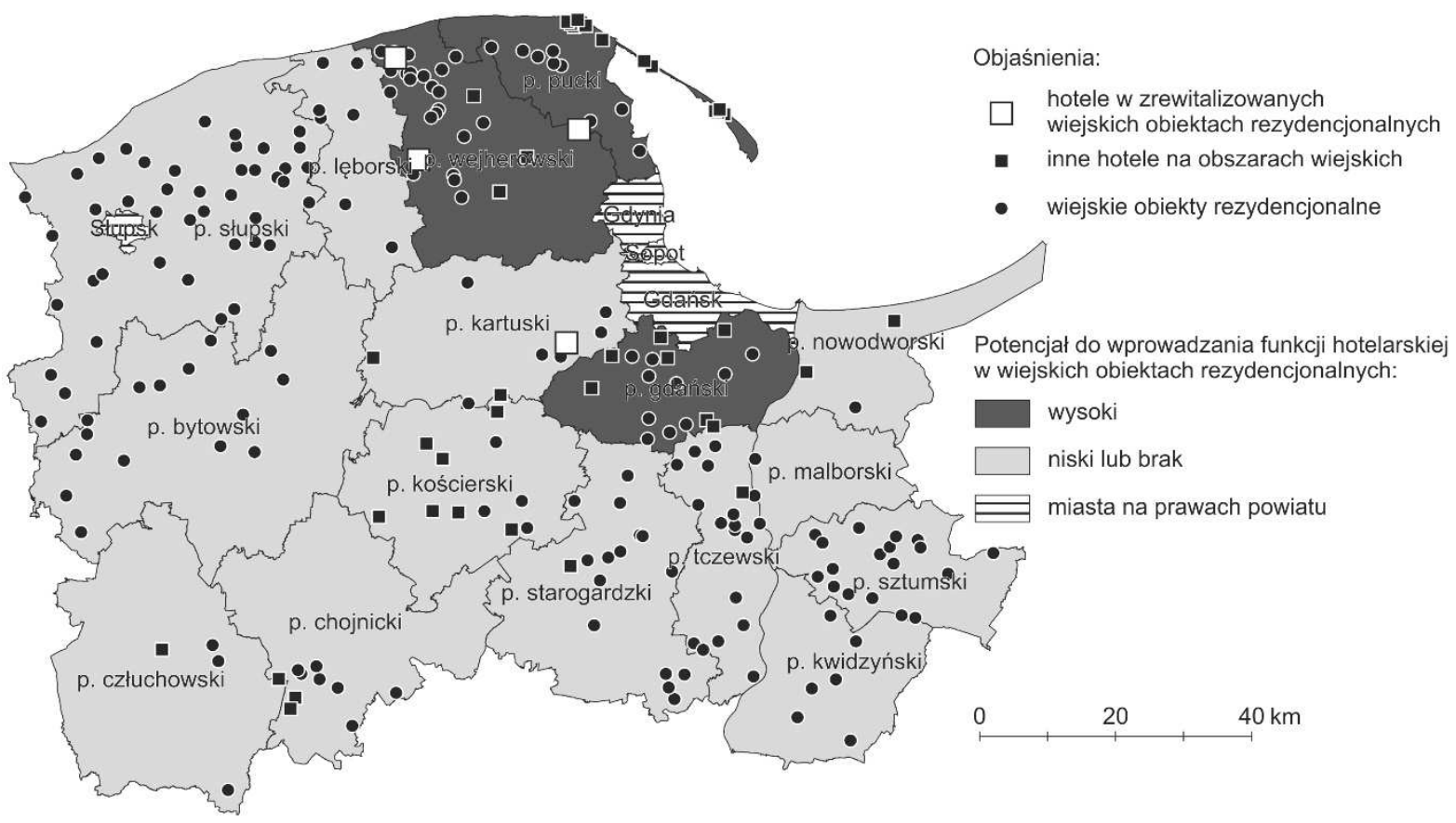

Rys. 2. Potencjał do wprowadzenia funkcji hotelarskiej w ramach rewitalizacji zabytkowych założeń pałacowo-parkowych na obszarach wiejskich województwa pomorskiego

Źródło: opracowanie własne na podstawie danych Pomorskiego Wojewódzkiego Konserwatora Zabytków w Gdańsku oraz Centralnego Wykazu Obiektów Hotelarskich 
tekturę stanowią nie tylko składnik lokalnej bazy noclegowej, ale same w sobie stanowią atrakcję turystyczną.

Potencjał do rewitalizacji obszarów wiejskich poprzez wprowadzenie funkcji hotelarskiej może być diagnozowany w dwutorowy sposób. Po pierwsze, przestrzeń powinna być ogólnie atrakcyjna dla potencjalnych inwestorów z sektora hotelarskiego. W literaturze wskazuje się, że w przestrzeni takiej powinny już funkcjonować inne hotele (KALNINS, CHUNG 2004, PAPATHEODOROU 2004, URTASUN, GUTIÉRREZ 2006). Przestrzenie atrakcyjne dla sektora hotelarskiego są zatem przestrzeniami koncentracji omawianych usług. Po drugie, na badanym obszarze powinny występować obiekty zabytkowe o szczególnie wysokim potencjale dla wprowadzenia funkcji hotelarskiej. Wśród nich wskazać można zespoły dworsko-parkowe i pałacowo-parkowe (KIZIELEWICZ 2002). Można zatem twierdzić, że potencjał do rewitalizacji obszarów wiejskich poprzez wprowadzenie funkcji hotelarskiej zależeć będzie od jednoczesnej koncentracji już istniejących hoteli oraz dużych zabytkowych obiektów rezydencyjnych, perspektywicznych dla wprowadzanej funkcji hotelarskiej.

Oceny potencjału rewitalizacji obszarów wiejskich poprzez wprowadzenie funkcji hotelarskiej dokonano w następujący sposób. Po pierwsze, ustalono powiaty, w przypadku których liczba hoteli działających na terenach wiejskich jest większa niż mediana (jeden obiekt). Po drugie, wskazano powiaty, na terenie których zlokalizowana jest większa niż mediana (osiem obiektów) liczba zabytkowych założeń rezydencyjno-parkowych. Część wspólna obu zbiorów pozwoliła wskazać obszary jednoczesnej koncentracji hoteli działających na terenach wiejskich i założeń pałacowo-parkowych, dworsko-parkowych czy folwarcznych. W ten sposób, powiaty gdański, pucki i wejherowski uznano za perspektywiczne dla rozwoju funkcji hotelarskiej w ramach rewitalizacji obszarów wiejskich województwa pomorskiego (rys. 2). Warto zauważyć, że we wspomnianym powiecie wejherowskim zlokalizowane sa trzy z czterech zrealizowanych projektów rewitalizacyjnych.

Wydaje się, że wprowadzenie funkcji hotelarskiej możliwe jest szczególnie w przypadku rewitalizacji założeń pałacowo-parkowych zlokalizowanych w niewielkiej odległości od dużych miast, dobrze z nimi skomunikowanych (GONDA-SOROCZYŃSKA, SOROCZYŃSKA 2014, KRONENBERG 2011). Z tej perspektywy szczególnym potencjałem dla ekonomicznie efektywnego rozwoju hotelarstwa charakteryzować się będą obszary wiejskie zlokalizowane w obszarze funkcjonalnym Trójmiasta. Potwierdzają to wcześniejsze analizy dotyczące lokalizacji hoteli i przestrzennego zróżnicowania cen oferowanych usług (NAPIERAŁA 2013). Warto jednocześnie podkreślić, że nagromadzenie założeń pałacowo-parkowych w peryferyjnych strefach dużych ośrodków miejskich nie jest czymś oryginalnym dla Pomorza (MYGA-PIĄTEK 2012). Z perspektywy rozwoju funkcji hotelarskiej w rewitalizowanych wiejskich obiektach rezydencjalnych, to właśnie ta strefa ma największy potencjał.

Z drugiej strony należy zwrócić uwagę na szczególną sytuację peryferyjnie położonego powiatu słupskiego. Jest to obszar, na którym występuje najwięcej wiejskich zabytkowych zespołów rezydencjonalnych (aż 43). Z tej perspektywy potencjał dla wprowadzenia funkcji hotelarskiej w ramach rewitalizacji zabytkowych założeń pałacowo-parkowych czy dworsko-parkowych jest zdecydowanie największy. Jednocześnie na terenach wiejskich powiatu nie prowadzą działalności jakiekolwiek skategoryzowane hotele. Niekorzystne czynniki lokalizacyjne (przede wszystkim brak stymulującej konkurencji, typowej dla obszarów funkcjonalnych dużych miast) okazały się wystarczającą barierą introdukowania skategoryzowanych hoteli w ramach rewitalizacji wiejskich zespołów rezydencjonalnych, jak również hoteli w ogóle. R. ROUBA (2010) uważa, że unikatowe walory kulturowe, architektoniczne i krajobrazowe hoteli działających w założeniach pałacowo-parkowych rekompensują potencjalnym klientom niedostatki lokalizacyjne. Analiza przypadków województwa pomorskiego dowodzi jednak, że teza być może jest prawdziwa w odniesieniu do generalnie rozpatrywanych obiektów hotelarskich, nie można jej jednak potwierdzić dla odrębnie analizowanych skategoryzowanych hoteli.

\section{PROBLEMY, WYZWANIA I KORZYŚCI REWITALIZACJI WIEJSKICH ZAŁOŻEŃ PAEACOWO-PARKOWYCH W WOJEWÓDZTWIE POMORSKIM POPRZEZ WPROWADZENIE FUNKCJI HOTELARSKIEJ}

Rewitalizacja obiektów zabytkowych na obszarach wiejskich odgrywa ogromną rolę w procesie odnowy wsi, a w konsekwencji także w rozwoju lokalnym. Bardzo ważne jest, aby wszelkie działania prowadzone były w taki sposób, by nie dopuścić do utraty wiejskiej specyfiki obiektu i jego otoczenia (WILCZYŃSKI 2009). Dodatkowo inicjatywy powinny prowadzić do odnowy wsi, podniesienia atrakcyjności danego miejsca oraz aktywizacji społeczności lokalnych (BAŃSKI, BEDNAREK-SZCZEPAŃSKA, CZAPIEWSKI 2009).

$\mathrm{Z}$ punktu widzenia władz gminy podejmowanie działań rewitalizacyjnych w obiektach zabytkowych przez prywatnych inwestorów ma bardzo duże znaczenie. Na tego typu inicjatywach gmina zyskuje 
przede wszystkim w wymiarze promocyjnym i wizerunkowym. Pozyskanie prywatnego inwestora jest bardzo często jedyną szansą na rewitalizację założeń pałacowo-parkowych, gdyż gminy wiejskiej nie stać najczęściej na tak kosztowną inwestycję. Gminy na Pomorzu obfitują w obiekty zabytkowe, głównie ze względu na historię tego regionu i wielokrotnie problematyczne jest zabezpieczenie w budżecie środków na bieżące utrzymanie tak dużego zabytkowego zasobu.

Jak podkreślano w przeprowadzonych wywiadach, współpraca na linii prywatny inwestor - władze gminy, oprócz obopólnych korzyści niesie ze sobą także potencjalne konflikty interesów. Hotelarze, zwłaszcza na początkowych etapach prowadzonych inwestycji, oczekują ulg z tytułu podatków i opłat lokalnych. Ze względu na powierzchnie zajmowane przez zespoły pałacowo-parkowe odprowadzony podatek od nieruchomości jest dość dużą kwotą, często prawie niemożliwą do uregulowania przez przedsiębiorcę w momencie, kiedy rewitalizowany obiekt nie przynosi jeszcze zysku. Z kolei władze gminy zobowiązane są do takiego formułowania przepisów podatkowych, żeby przedmiot zwolnienia nie był utajoną formą zwolnienia konkretnego podatnika. Uchwały rady gminy muszą zostać określone w taki sposób, aby dotyczyły potencjalnie nieoznaczonego indywidualnego podatnika. Jeśli możliwa staje się identyfikacja konkretnego przedsiębiorcy, który podlega zwolnieniu, to takie działanie oznacza przekroczenie ustawowej delegacji do ustanawiania zwolnienia przez radę gminy (Ustawa z 12 stycznia 1991 r. o podatkach $i$ opłatach lokalnych, Dz.U. 1991, nr 9, poz. 31).

Zarówno władze gminne, jak i hotelarze podkreślają, że dzięki działaniom rewitalizacyjnym na terenach wiejskich pojawia się turystyka sentymentalna. Do założeń pałacowo-parkowych na Pomorzu przyjeżdżają nie tylko potomkowie dawnych właścicieli, ale generalnie turyści z Niemiec, głównie ze względu na historię tych ziem. Jednocześnie powstające hotele stwarzają miejsca pracy dla lokalnej ludności. Ze względu na specyfikę miejsca tego typu obiekty wpływają pozytywnie na integrację społeczności lokalnych $\mathrm{z}$ samym hotelem, ale również z historią miejsca. Efekt jest wzmocniony, gdy hotele zlokalizowane w zabytkowych założeniach pałacowo-parkowych stają się miejscami organizacji różnego rodzaju wydarzeń kulturalnych.

Jak zauważono podczas przeprowadzonych wywiadów, hotele w zabytkowych założeniach pałacowo-parkowych na obszarach wiejskich są zwykle przedsięwzięciami niezależnych przedsiębiorstw, gdyż sieci hoteli niechętnie inwestują w tego typu obiekty ze względu na koszty remontu i brak możliwości pełnego dostosowania obiektu do standardów sieci. Problematyczna bywa współpraca z wojewódz- kim konserwatorem zabytków, który wielokrotnie nakłada liczne obostrzenia w dostosowywaniu obiektów. Rozwiązania proponowane przez konserwatora często pociągają wysokie koszty remontu, zaś bez jego zgody żadne zmiany w ogóle nie są możliwe. Problematyczne są też zmiany w parkach otaczających dwory, gdyż często są one uznane za zabytkową zieleń parkową. $W$ wyniku długotrwałego niszczenia obiektów i utraty walorów na skutek np. sukcesji naturalnej, odtworzenie zieleni jest bardzo trudne. Co więcej część wpisów do rejestru nie precyzuje jednoznacznie zakresu i przedmiotu ochrony konserwatorskiej (SIKORA 2010).

\section{WNIOSKI}

Analizowany proces rewitalizacji zabytkowych założeń pałacowo-parkowych na obszarach wiejskich pełni kilka funkcji, które udało się zidentyfikować dzięki realizacji zaprezentowanego badania. Pierwszą zdiagnozowaną funkcją jest funkcja marketingowa. Efekt rewitalizacji jest korzystny wizerunkowo nie tylko dla przedsiębiorcy, ale również dla gminy i jej mieszkańców. Istotną funkcją omawianych działań rewitalizacyjnych będzie również funkcja kulturowa. Przy zachowaniu autentycznego przekazu historycznego rewitalizacja pozwala odtworzyć związki mieszkańców z lokalnym dziedzictwem, a działania prowadzone we współpracy $\mathrm{z}$ władzami gminy mają znaczący potencjał kulturotwórczy. Wyniki zrealizowanych badań potwierdzają wcześniejsze oceny M. DURYDIWKI (2014). Z funkcją kulturową znakomicie koresponduje funkcja edukacyjna.

Kluczową funkcją badanych działań rewitalizacyjnych jest funkcja ekonomiczna. Wykorzystanie zespołów pałacowo-parkowych jako obiektów hotelowych stanowi właściwy kierunek zagospodarowania, gdyż gwarantuje ich dużą dostępność zarówno dla potencjalnych turystów, jak i mieszkańców. Z perspektywy ekonomicznej szczególnie efektywna będzie rewitalizacji założeń pałacowo-parkowych znajdujących się w bezpośrednim sąsiedztwie dużych miast. Produkt oferowany przez omawiane hotele jest produktem luksusowym, co zgodne jest z prestiżowym charakterem wcześniejszej funkcji rezydencjonalnej. Ekonomicznie efektywne funkcjonowanie omawianych hoteli możliwe jest przede wszystkim w strefie funkcjonalnej dużego miasta, dobrze skomunikowanej z miejscem zamieszkania potencjalnego nabywcy. Uzyskane wyniki zgodne są z wynikami wcześniejszych prac (CUDNY, ROUBA 2012, KONIECZNA-DOMAŃSKA 2015, ROUBA, CUDNY 2011).

Rewitalizacja zabytkowych założeń pałacowo-parkowych jest z perspektywy budżetu gminy wiejskiej 
na tyle dużym obciążeniem, że bez zaangażowania $\mathrm{w}$ ten proces prywatnego inwestora takie działanie jest praktycznie niemożliwe. Natomiast wprowadzenie w ramach rewitalizacji omawianych obiektów funkcji hotelarskiej ma możliwie najlepsze ekonomiczne efekty. W związku z powyższym pojawia się zrozumienie samorządu dla wsparcia prywatnych inicjatyw rewitalizacyjnych, a $z$ drugiej strony oczekiwanie tego wsparcia po stronie hotelarzy. Oczywiście musi zostać wypracowany kompromis między możliwym a oczekiwanym poziomem wsparcia.

\section{BIBLIOGRAFIA}

BAŃSKI J., BEDNAREK-SZCZEPAŃSKA M., CZAPIEWSKI K., 2009, Miejsce obszarów wiejskich $w$ aktualnych strategiach rozwoju województw - kierunki i cele rozwoju a rzeczywistość, „Studia Obszarów Wiejskich", t. 19, IGiPZ PAN, PTG, Warszawa.

BIEŃKOWSKI A., 2001, Turystyka jako forma rewitalizacji terenów wiejskich, „Zeszyty Naukowe Ostrołęckiego Towarzystwa Naukowego", 15, s. 83-94.

CUDNY W., ROUBA R., 2012, Hotelarstwo jako sposób na rewitalizacje zabytkowych obiektów militarnych pochodzacych z XIX $i$ XX wieku, „Ochrona Zabytków”, 3-4, s. 107-122.

DURYDIWKA M., 2014, Między tradycją a nowoczesnościa. Wybrane aspekty przemian kulturowych pod wptywem turystyki na przykładzie regionów recepcyjnych, „Turystyka Kulturowa”, 10, s. 34-51.

GAWE€ I., 2013, Wspótczesna oferta hotelowa dawnych rezydencji ziemiańskich w okolicach Stupska, Uniwersytet im. Adama Mickiewicza w Poznaniu; http://bibliotekacyfrowa.eu/dlibra/ docmetadata?id=37261.

Gminny program opieki nad zabytkami gminy Somonino na lata 2017-2020, 2017, Somonino; http://bip.somonino.pl/po bierz/3203.

Gminny program opieki nad zabytkami w gminie Choczewo na lata 2017-2020, 2017, Choczewo; http://www.choczewo.com. $\mathrm{pl} /$ wp-content/uploads/2017/03/Uchwala-Nr-XXXVII-222 -17-Rady-Gminy-Choczewo-z-dnia-15-lutego-2017-r.-w-spra wie-przyjecia-Gminnego-programu-Opieki-nad-Zabytkamiw-Gminie-Choczewo.pdf.

GONDA-SOROCZYŃSKA E., 2008, Funkcja turystyczno-rekreacyjna wsi, "Acta Scientiarum Polonorum Architectura", 7, 1, s. 63-80.

GONDA-SOROCZYŃSKA E., SOROCZYŃSKA A.M., 2014, Możliwości $i$ bariery $w$ przekształceniach funkcjonalno-przestrzennych wsi Piotrówek - studium przypadku, „Prace Naukowe Uniwersytetu Ekonomicznego we Wrocławiu”, 339, s. 23-36.

KALNINS A., CHUNG W., 2004, Resource-seeking agglomeration: A study of market entry in the lodging industry, "Strategic Management Journal", 25, 7, s. 689-699.

KIZIELEWICZ J., 2002, Wykorzystanie zespołów dworsko-parkowych i pałacowo-parkowych województwa pomorskiego dla celów turystycznych, Zamki gotyckie na szlakach turystycznych Pomorza, Kujaw, Warmii i Mazur, Międzynarodowa Konferencja Naukowa, Malbork 25-26 kwietnia 2002, Wyższa Szkoła Turystyki i Hotelarstwa w Gdańsku, Gdańsk, s. 36-42.

KONIECZNA-DOMAŃSKA A., 2015, Turystyka jako sposób komercjalizacji kultury na przykładzie hoteli w obiektach zabytkowych, „Zeszyty Naukowe Turystyka i Rekreacja”, 16, 2, s. 179192.
KORELESKI K., 2007, Koncepcja rozwoju zrównoważonego w unijnej polityce ksztattowania obszarów wiejskich, „Infrastruktura i Ekologia Terenów Wiejskich", 1, s. 19-26.

KOZAK M., 2008, Dwory, pałace i zamki - kosztowne pamiątki czy zasób w rozwoju?, "Studia Regionalne i Lokalne”, 32, 2, s. 92-111.

KRONENBERG J., 2011, Zrównoważony rozwój a powiązanie z miejscem i lokalna społecznościq - dwór w Tomaszowicach, "Zrównoważony Rozwój - Zastosowania", 2, s. 52-65.

Kvale S., 2011, Prowadzenie wywiadów, Wyd. Naukowe PWN, Warszawa.

LEŚNIEWSKA-NAPIERAŁA K., 2017, The potential of cultural heritage of national minorities in small towns - the case of Brzeziny, "Space - Society - Economy”, 19, s. 105-120.

LITWIN U., BACIOR S., PIECH I., 2010, Nowoczesne metody wartościowania krajobrazu, „Infrastruktura i Ekologia Terenów Wiejskich", 3, s. 147-155.

MAKOWSKA M., BOGUSZEWSKI R., 2013, Analiza danych zastanych - zagadnienia wstępne, [w:] M. Makowska (red.), Analiza danych zastanych: Przewodnik dla studentów, Wyd. Naukowe Scholar, Warszawa, s. 9-31.

MIKA M., 2007, Przemiany pod wptywem turystyki na obszarach recepcji turystycznej, [w:] W. Kurek (red.), Turystyka, Wyd. Naukowe PWN, Warszawa, s. 406-482.

MYGA-PIĄTEK U., 2012, Krajobrazy kulturowe. Aspekty ewolucyjne i typologiczne, Uniwersytet Śląski, Katowice.

NAPIERAŁA T., 2013, Przestrzenne zróżnicowanie cen ustug hotelowych w Polsce, Wyd. Uniwersytetu Łódzkiego, Łódź.

Pałac Ciekocinko, 2017; http:/ / ciekocinko.pl/; 20.11.2017.

PAPATHEODOROU A., 2004, Exploring the Evolution of Tourism Resorts, „Annals of Tourism Research", 31, 1, s. 219-237.

Program opieki nad zabytkami powiatu kartuskiego na lata 2015-2018, 2015, Starostwo Powiatowe w Kartuzach, Kartuzy; http:// www.kartuskipowiat.com.pl/pliki/PROGRAM Kartuzy_20 15_2018 aktualiacja.pdf.

Program opieki nad zabytkami powiatu puckiego na lata 2016-2019, 2016, Starostwo Powiatowe w Pucku, Puck; http://edzien nik.gdansk.uw.gov.pl/WDU_G/2016/3068/oryginal/Zalac znik1.pdf.

RATAJSKI L., 1973, Metodyka kartografii społeczno-gospodarczej, Państwowe Przedsiębiorstwo Wydawnictw Kartograficznych, Warszawa.

ROUBA R., 2010, Hotelarstwo w zabytkowych rezydencjach jako czynnik modyfikujący otoczenie, Łódzkie Towarzystwo Naukowe, Łódź.

ROUBA R., CUDNY W., 2011, Monitorowanie zabytkowych rezydencji funkcjonujacych na rynku ustug hotelarskich w Polsce w latach 2002-2011, „Ochrona Zabytków”, 1-4, s. 183-198.

Rozporzadzenie Ministra Gospodarki i Pracy z 19 sierpnia 2004 r. $w$ sprawie obiektów hotelarskich $i$ innych obiektów, w których sq świadczone ustugi hotelarskie, Dz.U. 2004, nr 188, poz. 1945 z późn. zm.

SALISZCZEW K.A., 1998, Kartografia ogólna, Wyd. Naukowe PWN, Warszawa.

SIKORA D., 2010, Parki historyczne w rejestrze zabytków - ustalenie przedmiotu i zakresu ochrony, problemy weryfikacji rejestru, granice ochrony konserwatorskiej, „Kurier Konserwatorski”, 7, s. 11-16.

Strategia rozwoju gminy Łęczyce na lata 2010-2025, 2010, Łęczyce; http://www.leczyce.pl/images/dokumenty_pdf/strategia_ rozwoju_gminy.pdf.

Strategia rozwoju gminy Somonino na lata 2012-2019, 2012, Somonino, http://bip.somonino.pl/pobierz/1945. 
URTASUN A. I, GUTIÉRREZ I., 2006, Hotel location in tourism cities: Madrid 1936-1998, "Annals of Tourism Research”, 33, 2, s. 382-402.

Ustawa z 12 stycznia 1991 r. o podatkach i optatach lokalnych, Dz.U. 1991, nr 9, poz. 31.

Ustawa z 23 lipca 2003 r. o ochronie zabytków i opiece nad zabytkami, Dz.U. 2003, nr 162, poz. 1568 z późn. zm.

WILCZYŃSKI R., 2009, Jak rozwijać obszary wiejskie, aby przeciwdziałać kryzysowi zagospodarowania przestrzennego?, Polskie krajobrazy wiejskie dawne i wspótczesne, „Prace Komisji Krajobrazu Kulturowego", 12, s. 193-197.
WiTKOWSKI K., STAROŚCIC D., 2008, System infrastruktury spotecznej w gminie, „Studia Lubelskie”, IV, s. 177-194.

WŁODARCZYK B., 2011, Procesy ksztattujące przestrzeń turystyczna, „Turyzm/Tourism”, 21, 1-2, s. 59-66.

YIN R.K., 2015, Studium przypadku w badaniach naukowych, Wyd. Uniwersytetu Jagiellońskiego, Kraków.

Artykuł wpłyną: 7 listopada $2017 \mathrm{r}$. Zaakceptowano do druku: 18 grudnia $2017 \mathrm{r}$. 